\title{
Pengembangan Media Pembelajaran Planetarium Gerhana sebagai Alat Bantu dalam Pembelajaran Ilmu Pengetahuan Bumi Antariksa (IPBA) pada Materi Gerhana
}

\author{
Vera Siska Pratiwi, Afrizal Mayub, Dedy Hamdani \\ Program Studi Pendidikan Fisika, Jurusan Pendidikan MIPA \\ Fakultas Keguruan dan Ilmu Pendidikan Universitas Bengkulu \\ Jl. WR. Supratman Kandang Limun, Bengkulu \\ e-mail : verasiskaberutu2@gmail.com
}

\begin{abstract}
ABSTRAK
Penelitian ini bertujuan untuk mengembangkan media pembelajaran planetarium gerhana untuk pembelajaran IPBA. Mengetahui hasil uji coba media pembelajaran planetarium gerhana pada pembelajaran IPBA. Mengetahui respon dari para responden terhadap media pembelajaran planetarium gerhana yang telah dikembangkan secara teoritis pada pembelajaran IPBA. Jenis penelitian ini adalah Research and Development, subjek penelitian ini adalah guru fisika SMA Pelita Kasih. Penelitian pengembangan ini menggunakan metodologi 4D (Define, Design, Development, and Disseminate). Penilaian dan validasi produk media pembelajaran planetarium gerhana ini telah dilakukan oleh ahli materi, ahli media. Berdasarkan hasil analisis data kemudian diinterprestasikan dengan skala 5 menurut Sukarja, dihasilkan kriteria penilaian media sangat baik dengan analisis penilaian media menurut ahli materi menunjukkan kualitas sangat baik dengan persentase keidealan $85,4 \%$ dan layak untuk digunakan. Penilaian media menurut ahli media menunjukkan kualitas Baik dengan persentase keidealan 77,3\% terkait dengan segala aspek yang ada pada media yang telah dikembangkan dan layak untuk digunakan dengan sedikit koreksi untuk perbaikan media tersebut. Sehingga media tersebut dapat menunjang ketertarikan pelajar dalam pembelajaran.
\end{abstract}

Kata kunci: Pengembangan, Media Pembelajaran, Planetarium Gerhana.

\begin{abstract}
This study aims to develop eclipse planetarium learning media for IPBA learning. Knowing the results of testing of eclipse planetarium learning media on IPBA learning. Knowing the responses of respondents to eclipse planetarium learning media that have been developed theoretically in IPBA learning. This type of research is Research and Development, the subject of this study was Pelita Kasih high school physics teacher. This development research uses the 4D methodology (Define, Design, Development, and Disseminate). Assessment and validation of eclipse planetarium learning media products have been carried out by material experts, media experts. Based on the results of data analysis and then interpreted with a scale of 5 according to Sukarja, the media assessment criteria produced very well with media assessment analysis according to material experts showed very good quality with a percentage of $85.4 \%$ ideal and suitable for use. Media assessment according to media experts shows Good quality with a percentage of $77.3 \%$ ideal related to all aspects that exist in the media that have been developed and are feasible to use with little correction for the improvement of the media. So that the media can support students' interest in learning.
\end{abstract}

Keywords: Development, Learning Media, Eclipse Planetarium.

\section{PENDAHULUAN}

Pada umumnya, para pelajar memiliki pandangan bahwa fisika merupakan mata pelajaran yang sulit dan pelajaran yang membosankan dan membingungkan. Seperti yang diketahui bahwa pola pendekatan matematis memang tidak bisa dihindari dalam pembelajaran fisika, terutama karena soal dan kasus yang diajukan menuntut jawaban dalam bentuk angka beserta simbol dalam pembelajaran fisika.

Perkembangan teknologi saat ini semakin menonjol bahwa teknologi diciptakan memang karena tuntutan zaman yang semakin modern. Selain itu kebutuhan di setiap bidang membutuhkan 
teknologi yang mampu menyelesaikan pekerjaan manusia. Terutama yang dapat dilihat dengan jelas bahwa pendidikan saat ini tidak hanya memerlukan buku, papan tulis, dan gambar berupa 2D.

Tata surya merupakan bagian dari salah satu mata pelajaran Ilmu Pengetahuan Bumi Antariksa. Kurangnya pemahaman peserta didik terhadap materi yang ada pada mata pelajaran ini yang bersifat abstrak harus memiliki pemahaman dengan memainkan logika dan hayalan yang sulit. Pembelajaran yang dilakukan selama ini juga masih sebatas pada penjelasan konsep yang abstrak melalui ceramah dan ilustrasi melalui gambar di papan tulis serta viewer. Beberapa kali proses pembelajaran di kelas terpaksa tidak dapat diselesaikan mengingat keterbatasan waktu yang ada.

Media yang sudah ada di laboratorium salah satunya adalah alat peraga planetarium yang fungsinya kurang digunakan karena alat peraga tersebut masih menggunakan bantuan manusia dan planetarium tersebut hanya terdapat matahari dan planet saja. Selain planetarium yang ada dalam bentuk alat peraga, planetarium juga terdapat dalam bentuk virtual reality karya Didik Mutaqqin yang bisa diamati secara langsung, namun aplikasi yang dibuat masih memiliki beberapa fitur yang kurang lengkap sehingga materi yang ada belum bisa disampaikan secara detail. Selain itu alat peraga Copernican Planetary karya Alan Coper juga masih mengunakan cara yang manual dengan cara memutarkan titik pusat yang sebagai titik acuan planerium tersebut. Sehingga kondisi pada pembelajaran IPBA tersebut tidak efisien dan belum efektif selama pembelajaran berlangsung.

Permasalahan di atas memerlukan usaha penyelesaian yang tidak mudah untuk dilakukan. Untuk meningkatkan pencapaian hasil belajar mata kuliah IPBA (Ilmu Pengetahuan Bumi Antariksa) diperlukan sebuah media yang akan dirancang lebih mudah lagi dari yang sebelumnya dengan menambahkan bagaian dari berbagai fitur yang memungkinkan untuk menyerupai bentuk yang sebenarnya dan membuat planetarium tersebut menjadi lebih mudah digunakan. Maka dari itu penulis membuat dan Mengembangakan Media Pembelajaran Planetarium Sebagai Alat Bantu Dalam Pembelajaran Ilmu Pengetahuan Bumi Antariksa. Dengan media ini dapat mempermudah peserta didik dalam menguasi pelajaran IPBA secara mendalam, dan dapat berinteraksi dengan objek-objek yang sesuai dengan pembelajaran yang berlangsung. Sehingga dengan adanya media pembelajaran yang menarik dan edukatif ini diharapkan mampu meningkatkan rasa ingin tahunya dalam pelajaran IPBA.

Adapun rumusan masalah pada penelitian ini adalah 1)Bagaimana mengembangkan media pembelajaran planetarium gerhana untuk pembelajaran IPBA? 2)Apakah hasil ujicoba media pembelajaran planetarium gerhana sudah layak untuk digunakan pada pembelajaran IPBA? 3)Bagaimana respon para responden terhadap media pembelajaran planetarium gerhana yang telah dikembangkan secara teoritis pada pembelajaran IPBA? Dengan tujuan penelitian sebagai berikut: 1)Untuk mengembangkan media pembelajaran planetarium gerhana untuk pembelajaran IPBA. 2)Mengetahui hasil uji coba media pembelajaran planetarium gerhana pada pembelajaran IPBA. 3)Mengetahui respon dari para responden terhadap media pembelajaran planetarium gerhana yang telah dikembangkan secara teoritis pada pembelajaran IPBA.

\section{METODE PENELITIAN}

Metode penelitian yang digunakan adalah metode penelitian dan pengembangan (Research and Development). Penelitian dan pengembangan media pembelajaran planetarium gerhana mengacu pada model $4 D$ yang dikemukakan oleh Thiagarajan sebagaimana yang dikutip oleh Sugiyono[1]. Model pengembangan $4 D$ (four-D models) terdiri atas 4 tahap yaitu tahap pendefinisian (define), tahap perencanaan (design), tahap pengembangan (develop), dan tahap penyebaran (disseminate). Karena hasil penelitian ini tidak disebarkan pada Instansi/Lembaga lain (selain tempat penelitian) maka hanya digunakan tiga tahap, yaitu sampai tahap pengembangan (develop).

Tahap pendefinisian merupakan tahap untuk menetapkan dan mendefinisikan syarat-syarat dalam pembelajaran. Tahap pendefinisian dapat berupa observasi kegiatan pembelajaran untuk memperoleh informasi. Tahap perancangan digunakan untuk merancang instrumen pengambilan data, perancangan media dan perangkat pembelajaran yang akan dilaksanakan di kelas. Tujuan dari tahap desain adalah untuk menyusun instrumen penelitian, merancang format dan bentuk media. Tahap pengembangan terdiri dari penilaian ahli dan uji pengembangan produk. Tahap 
pengembangan media disesuaikan dengan hasil rancangan media pada tahap perancangan yang berisi berbagai instrumen penelitian yang sebelumnya sudah dikonsultasikan dan mendapat persetujuan dari dosen pembimbing.

\section{HASIL DAN PEMBAHASAN}

Pada penelitian ini harus diketahui terlebih dahulu bahwa Pembelajaran fisika merupakan gabungan dari dua kata, yaitu 'pembelajaran' dan 'fisika'. Untuk memahaminya, perlu diuraikan makna pembelajaran dan makna fisika. Pembelajaran merupakan suatu proses yang terdiri dari kombinasi dua aspek yaitu belajar dan mengajar. Belajar tertuju kepada apa yang harus dilakukan oleh siswa, sedangkan mengajar berorientasi pada apa yang harus dilakukan oleh pendidik sebagai pemberi pelajaran. Kedua aspek ini akan berkolaborasi secara terpadu menjadi suatu kegiatan pada saat terjadi interaksi antara pendidik dengan siswa, serta antara siswa dengan siswa disaat pembelajaran berlangsung[2]. Media pembelajaran merupakan suatu teknologi pembawa pesan yang dapat digunakan untuk keperluan pembelajaran; media pembelajaran merupakan sarana fisik untuk menyampaikan materi pembelajaran. Media pembelajaran merupakan sarana komunikasi dalam bentuk cetak maupun pandang dengar termasuk teknologi perangkat keras[3].

Adapun hasil penelitian tang sudah dilkukan adalah seperti gambar berikut:

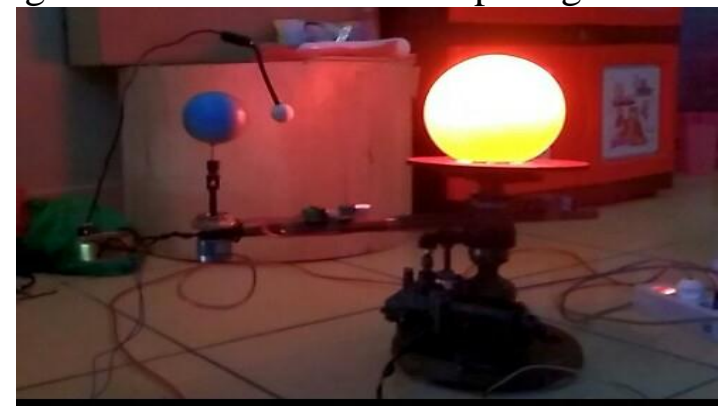

Gambar 1. Media yang telah dikembangkan

Sehingga, data penilaian yang sudah dilakukan oleh ahli materi dan ahli media dapat dilihat pada tabel 1 dan 2. Data yang didapat dari para ahli terhadap media pembelajaran gerhana dianalisis untuk mendapatkan kesimpulan terhadap media pembelajaran gerhana yang telah dibuat.

Tabel 1. Data Skor Validasi Oleh Tim Ahli Media Terhadap Media Pembelajaran Planetarium Gerhana

\begin{tabular}{|c|c|c|c|}
\hline Ahli & $\begin{array}{c}\text { Rata- } \\
\text { rata }\end{array}$ & $\begin{array}{c}\text { Persen } \\
\text { tase }(\boldsymbol{\%})\end{array}$ & Kategori \\
\hline 1 & 3,57 & 71,57 & Baik \\
\hline 2 & 4,15 & 83,07 & Sangat Baik \\
\hline Rata-rata & 3.86 & 77,32 & Baik \\
\hline
\end{tabular}

Berdasarkan tabel 1. Diatas dilihat bahwa data dari tim ahli media yang bertindak sebagai validator untuk media pembelajaran gerhana. Rata-rata yang di dapat dari ahli 1 adalah sebesar 3,57 dengan persentase kelayakan 71,57\% kategori Baik. Sedangkan rata-rata yang didapat dari ahli 2 adalah sebesar 4,15 dengan persentase kelayakan 83,07\% kategori Sangat Baik. Berdasarkan ratarata dari dua orang ahli tersebut didapat skor rata-rata sebesar 3.86 dengan persentase kelayakannya 77,32\%, sehingga dapat dikatakan bahwa hasil uji coba media pembelajaran planetarium gerhana ini dikategorikan Baik. Dari data rata-rata dan hasil persentase tim ahli media terhadap media pembelajaran planetarium gerhana telah memenuhi kriteria dengan kualitas baik. Artinya, baik dari segi isi ataupun teknis, media pembelajaran planetarium gerhana ini memiliki kualitas baik dan dapat digunakan dalam pembelajaran. 
Tabel 2. Data Skor Validasi Oleh Tim Ahli Materi Terhadap Media Pembelajaran Planetarium Gerhana

\begin{tabular}{|c|c|c|c|}
\hline Ahli & $\begin{array}{c}\text { Rata- } \\
\text { rata }\end{array}$ & $\begin{array}{c}\text { Persen } \\
\text { tase }(\boldsymbol{\%})\end{array}$ & Kategori \\
\hline 1 & 4,38 & 87,7 & Sangat Baik \\
\hline 2 & 4,15 & 83,07 & Sangat Baik \\
\hline $\begin{array}{c}\text { Rata- } \\
\text { rata }\end{array}$ & 4,27 & 85,39 & Sangat Baik \\
\hline
\end{tabular}

Berdasarkan tabel 2. Diatas dilihat bahwa data dari tim ahli media yang bertindak sebagai validator untuk media pembelajaran gerhana. Rata-rata yang di dapat dari ahli 1 adalah sebesar 4,38 dengan persentase kelayakan $87,7 \%$ kategori Sangat Baik. Sedangkan rata-rata yang didapat dari ahli 2 adalah sebesar 4,15 dengan persentase kelayakan 83,07\% kategori Sangat Baik. Berdasarkan rata-rata dari dua orang ahli tersebut didapat skor rata-rata sebesar 4,27 dengan persentase kelayakannya $85,39 \%$, sehingga dapat dikatakan bahwa hasil uji coba media pembelajaran planetarium gerhana ini dikategorikan Sangat Baik. Dari data rata-rata dan hasil persentase tim ahli media terhadap media pembelajaran planetarium gerhana telah memenuhi kriteria dengan kualitas sangat baik. Artinya, Sangat baik dari segi isi ataupun teknis, media pembelajaran planetarium gerhana ini memiliki kualitas baik dan dapat digunakan dalam pembelajaran.

Hasil penelitian yang telah dilakukan menunjukkan bahwa media pembelajaran yang dikembangkan layak untuk digunakan dalam proses pembelajaran. Hal ini ditunjukkan dengan diperolehnya data-data yang telah memenuhi syarat sebagai media yang layak. Media pembelajaran yang dikembangkan adalah media pembelajaran planetarium gerhana pada mata pelajaran IPBA (ilmu pengetahuan bumi antariksa). Berdasarkan hasil evaluasi dari tim ahli, dan uji coba pemakaiannya, kajian tentang produk pengembangan media pembelajaran gerhana yang meliputi kesesuaian produk yang dihasilkan dengan tujuan penelitian (pengebangan).

Sedangkan hasil penelitian yang berkaitan dengan penelitian ini adalah: 1) hasil penelitian yang telah dilakukan oleh Myrna Rahmawati dan Khaerunnisa (2018) dengan judul Perbandingan Hasil Belajar Melalui Alat Peraga Maket Gerhana Dan Video Pembelajaran, menunjukkan bahwa Hasil Belajar melalui video pembelajaran lebih baik daripada Hasil Belajar melalui alat peraga maket gerhana. Hal ini dapat dibuktikan dengan rata-rata nilai Hasil Belajar melalui video pembelajaran sebesar 51,67 lebih besar dari rata-rata nilai Hasil Belajar melalui alat peraga sebesar 50,33[4]; 2) Penelitian yang telah dilakukan oleh Jody Prariyadi dengan judul "PENGEMBANGAN APLIKASI MOBILE LEARNING FISIKA BERBASIS SMARTPHONE ANDROID PADA POKOK BAHASAN KETERATURAN GERAK PLANET SEBAGAI SASARAN UNTUK MEMFASILITASI KEMAMPUAN ANALISIS SISWA KELAS XII SMA" menunjukkan bahwa hasil penelitian ini adalah kualitas aplikasi mobile learning yang telah dikembangkan adalah sangan baik (SB) berdasarkan penilaian ahli media $92,86 \%$, ahli materi $93,75 \%$, dan guru fisika 91,07\%. Respon siswa pada uji coba terbatas adalah setuju (S) 73,70\%, sedangkan respon siswa pada uji coba luas adalah setuju (S) $80,11 \%$ [5]; 3) Penelitian Delana Gita Pertiwi dengan judul "RANCANG BANGUN APLIKASI PEMBELAJARAN TATA SURYA BERBASIS MULTIMEDIA DI KELAS IX SMPN 157 JAKARTA TIMUR (STUDI KASUS: MATAHARI DAN BINTANG)" menunjukan bahwa output yang dihasilkan berupa aplikasi pembelajaran multimedia interaktif dalam bentuk CD (Compact Disc) dengan kapasitas $462 \mathrm{MB}$ dan resolusi layar 1024x768 pixel dimana di dalamnya menampilkan visualisasi Matahari sebagai Bintang, aplikasi ini cukup userfriendly. Dapat disimpulkan bahwa aplikasi multimedia ini bermanfaat untuk bidang pendidikan ksususnya dalam mempelajari ilmu pengetahuan tata surya yaitu matahari[6]; 4) Penelitian yang dilakukan oleh Didik Muttaqin, dkk ( 2016) dengan judul PLANETARIUM “ APLIKASI PEMBELAJARAN SISTEM TATA SURYA BERBASIS VIRTUAL REALITY” menunjukkan bahawa dengan menggunakan aplikasi planetarium yang ditunjukkan khususnya pada siswa sudah sesuai dengan kurikulum 2013. Dimana aplikasi ini menggunakan teknologi yang membuat pengguna dapat berinteraksi dengan suatu lingkungan baru yang hanya ada pada komputer[7]; 5) Penelitian Dedynggego, dkk dengan judul "PERANCANGAN MEDIA 
PEMBELAJARAN INTERAKTIF 3D TATA SURYA MENGGUNAKAN TEKNOLOGI AUGMENTED REALITY UNTUK SISWA KELAS 6 SEKOLAH DASAR SANGIRA” menunjukkan bahwa dengan menggunakan media pembelajaran interaktif 3D Tata Surya, dosen dapat lebih mudah memberikan materi karena didukung dengan tampilan objek 3D planet pada aplikasi dan suara penjelasan spesifikasi setiap planet, sehingga proses pembelajaran dapat mencapai efisiensi dan efektifitas[8].

\section{KESIMPULAN DAN SARAN}

Dari hasil penelitian yang telah dilakukan sesuai dengan tujuan penelitian yang dirancang sebelumnya. Dan berdasarkan analisis data serta pembahasan sebelumnya, maka dapat disimpulkan bahwa, Media pembelajaran planetarium gerhana pada pembelajaran IPBA dikembangkan dengan menggunakan model pengembangan 4-D menurut Thiagarajan, dkk yang terdiri dari 4 tahap yaitu tahap pendefinisian (define), tahap perancangan (design), tahap pengembangan (develop), dan tahap penyebaran (dessiminate). Dengan metode ini telah menghasilkan produk media pembelajaran planetarium gerhana dan sesuai dengan tahap pengembangan yang telah dilakukan. Hasil uji coba media pembelajaran planetarium gerhana yang telah dikembangkan dapat diketahui dengan melakukan tahap validasi oleh ahli media dan ahli materi. Hasil persentase penilaian dari ahli media adalah sebesar $77,32 \%$ dengan kriteria layak untuk digunakan dalam pembeajaran.

Dan hasil dari ahli materi adalah sebesar $85,38 \%$ dengan kriteria sangat layak untuk digunakan dalam pembelajaran. Maka dapat disimpulkan bahwa media pembelajaran yang telah dikembangkan layak untuk digunakan dalam pembelajaran. Respon yang diberikan terhadap media pembelajaran planetarium gerhana yang telah dikembangkan berdasarkan penilaian para ahli dan guru dalam segala aspek pembelajaran secara keseluruhan termasuk dalam kriteria baik/layak untuk digunakan dalam pembelajaran.

Karena pada penelitian ini hanya sampai pada tahap pengembangan saja maka perlu dilakukan uji coba kepada responden secara luas dan perlu dilakukan pengembangan media pembelajaran secara keseluruhan sehingga akan meningkatkan kualitas media pembelajaran yang digunakan serta dapat melihat hasil akhir dari penelitian ini. Apabila ada yang ingin meneruskan atau membuat penelitan yang sama maka peneliti hanya melakukan tahap uji coba terhadap peserta didik agar terbukti layak dan untuk seterusnya media yang dikembangkan layak untuk digunakan dalam pembelajaran.

\section{DAFTAR PUSTAKA}

[1] Sugiyono. 2017. Metode PenelitianPendidikan Pendekatan Kuantitatif Kualitatif dan R\&D. Bandung: Alfabeta.

[2] Jihad, A., \& Haris, A. 2012. Evaluasi Pembelajaran. Yogyakarta: Multi Pressindo.

[3] Rusman, dkk. 2013. Pembelajaran Berbasis Teknologi Informasi dan Komunikasi . Jakarta: PT RajaGrafindo Persada.

[4] Rahmawati, Myrna \& Khaerunnisa. 2018. Perbandingan Hasil Belajar Melalui Alat Peraga Maket Gerhana Dan Video Pembelajaran. Jurnal Ilmiah PGSD ISSN: 2579-6151. Vol .1

[5] Prariyadi, J. 2014. Pengembanagan Aplikasi Mobile Learning Fisika Berbasis Android Pada Pokok Bahasan Keteraturan Gerak Planet Sebagai Sasaran Untuk Memfasilitasi Kemampuan Analisis Siswa Kelas XI SMA. Yogyakarta: UIN Sunan Kalijaga.

[6] Pertiwi, D. G. 2014. Rancang Bangun Aplikasi Pembelajaran Tata Surya Berbasis Multimedia di Kelas IX SMPN 157 Jakarta Timur (Studi Kasus: Matahari dan Bintang). Jakarta: UIN Syarif Hidayatullah.

[7] Muttaqin, D., dkk. 2016. Aplikasi Pembelajaran Sistem Tata Surya Berbasis Virtual Reality. Planetarium, Vol.2(ISSN : 2442-5826), 713.

[8] Dedynggego, dkk. 2015. Perancangan Media Pembelajaran Interaktif 3D Tata Surya Menggunakan Teknologi Augmented Reality Untuk Siswa Kelas 6 Sekolah Dasar Sangira. Jurnal Elektronik Sistem Informasi dan Komputer, Vol.1. 